\title{
Prevalence of brucellosis and risk factors associated with its transmission to slaughterhouse employees in the Cuiaba metropolitan area in the state of Mato Grosso
}

\section{Prevalência da brucelose e fatores de risco associados a sua transmissão em trabalhadores de indústrias frigoríficas da região metropolitana de Cuiabá, Mato Grosso}

\author{
Rui Carlos Schneider ${ }^{1}$; Marcelo Diniz Santos ${ }^{2 *}$; Michele Lunardi; \\ Ana Helena Benetti²; Lázaro Manoel Camargo ${ }^{2}$; Silvio Henrique Freitas²; \\ Rísia Lopes Negreiro ${ }^{3}$; Deiler Sampaio Costa ${ }^{4}$
}

\begin{abstract}
The aim of this study was to investigate the prevalence of Brucella abortus infection in employees of two slaughterhouses (A and B) in the metropolitan area of Cuiabá in the state of Mato Grosso and the risk factors associated with its transmission. We collected 134 blood samples from workers in all sections of the slaughterhouses to evaluate brucellosis, and we administered a questionnaire to obtain information about potential risk factors associated with its transmission. We also collected blood from 468 cows during slaughter on the same day of the blood collection from the slaughterhouse workers to determine bovine seropositivity. Six (4.5\%) out of the 134 workers examined were positive for B. abortus infection, and all worked as slaughterers. We found a significant association between the prevalence of brucellosis and slaughterers compared to other occupations at the slaughterhouse. It is noteworthy that four seropositive workers had worked as a slaughterer in other establishments, they did not use personal protective equipment (PPE) and they had consumed dairy products without heat treatment. In assessing the prevalence of brucellosis in slaughtered animals in both slaughterhouses, there was a higher number of seropositive cows at slaughterhouse B than slaughterhouse A: of the 468 cows tested in both slaughterhouses, 35 (7.5\%) were positive for $B$. abortus infection, as determined by the 2-mercaptoethanol test (2-ME). Slaughterhouse workers are susceptible to infection by B. abortus, and it was noted that in both slaughterhouses, all of the seropositive workers were slaughterers. Cows that were positive for B. abortus were slaughtered in both slaughterhouses without proper sanitary procedures and necessary information for slaughter. Not using personal protective equipment and the slaughter of animals that are seropositive for brucellosis are risk factors for the transmission of the disease to slaughterhouse workers.
\end{abstract}

Key words: Brucellosis, risk factors, slaughterhouse and zoonosis

\footnotetext{
${ }^{1}$ Pesquisador, Mestre em Ciências da Saúde, Superintendente Administrativo Secretaria de Estado de Educação. E-mail: rschneider@seduc.mt.gov.br

${ }^{2}$ Profs. Faculdade de Medicina Veterinária da Universidade de Cuiabá, UNIC, Cuiabá, MT. E-mail: dinizms@uol.com.br; michelelunardi@gmail.com; ahbenetti@hotmail.com; lazaro.camargo@kroton.com.br; silviohfreitas@gmail.com

${ }^{3}$ Pesquisadora do Instituto de Defesa Agropecuário do Estado de Mato Grosso, INDEA, MT. E-mail: risianegreiros@yahoo.com. br

${ }^{4}$ Prof. Faculdade de Medicina Veterinária da Universidade Federal de Mato Grosso do Sul, UFMS, Campo Grande , MS. E-mail: deilercosta@yahoo.com.br

* Author for correspondence
} 


\section{Resumo}

O objetivo deste trabalho foi estudar a prevalência da infecção por Brucella abortus em trabalhadores de duas indústrias frigoríficas (A e B) na região metropolitana de Cuiabá, Mato Grosso, e os fatores de risco associados a sua transmissão. Foram colhidas 134 amostras de sangue dos trabalhadores, em todos os setores das indústrias, para exame de brucelose e aplicado questionário para levantamento de informações de possíveis fatores de risco associados à transmissão da doença. Realizou-se também, a colheita de sangue em 468 fêmeas bovinas durante o abate, no mesmo dia da colheita de sangue dos funcionários das indústrias pesquisadas, para identificação da soropositividade bovina. Dos 134 trabalhadores examinados, seis $(4,5 \%)$ foram reagentes para a infecção por B. abortus e todos trabalhavam na atividade de magarefe. Obteve-se associação significativa da prevalência de brucelose em magarefes, em relação às demais atividades desenvolvidas na indústria. Quatro trabalhadores soropositivos já haviam trabalhado na função de magarefe em outros estabelecimentos, não utilizavam equipamento de proteção individual (EPI) e já haviam consumido produtos lácteos sem tratamento térmico. Ao avaliar a prevalência de brucelose nos animais abatidos nas duas indústrias frigoríficas, encontrou-se maior número de fêmeas soropositivas na indústria $\mathrm{B}$ do que na indústria $\mathrm{A}$ onde, das 468 fêmeas com sangue colhidos nas duas indústrias, 35 (7,5\%) reagiram positivamente a infecção por $B$. abortus pela prova de 2-mercaptoetanol (2-ME). Trabalhadores das indústrias frigoríficas estão susceptíveis a contaminação por $B$. abortus, sendo observado nas indústrias que as pessoas soropositivas desenvolviam atividades de magarefe. Fêmeas bovinas soropositivas a $B$. abortus foram abatidas nas indústrias frigoríficas sem a devida informação e procedimentos sanitários necessários ao abate. As atividades de magarefe, a não utilização de EPI e o abate de animais soropositivos a brucelose são fatores de risco à transmissão da enfermidade para os trabalhadores da indústria frigorífica.

Palavras-chave: Brucelose, fatores de risco, frigorífico e zoonose

Brucellosis is a zoonotic disease that is directly or indirectly transmitted from animal reservoirs to human beings. The primary route of transmission is the ingestion of unpasteurized dairy products, but this infection is also considered occupational due to the higher incidence observed in specific occupational groups exposed to infected animals (GODFROID et al., 2005). Human brucellosis is a systemic disease that initially manifests through nonspecific symptoms, such as fever, fatigue, malaise, weight loss, headache, arthralgia, myalgia and chills. Sweating can also be observed. In addition to these clinical manifestations, the involvement of musculoskeletal, dermal, gastrointestinal, respiratory, cardiovascular and neurological systems can occur (GODFROID et al., 2011).

Currently, the genus Brucella, which is classified within the family Brucellaceae, in composed of ten species: B. melitensis, B. abortus, B. suis, $B$. neotomae, B. ovis, B. canis, B. ceti, B. pinnipedialis, $B$. microti and B. inopinata. Their preferred hosts are goats, sheep, cattle, pigs, rodents, sheep, dogs, cetaceans, pinnipeds, wild rodents and an unknown host, respectively (GODFROID et al., 2011).

In mammals, the life cycle of Brucella spp. is established in the intracellular environment of the host. During pregnancy, intense replication is commonly observed in placental trophoblasts, which culminates in the disintegration of their structure and predisposes the occurrence of miscarriages (NETA et al., 2010).

In cattle, brucellosis results in economic losses because of its association with infertility and miscarriages. In this species, the disease is mainly caused by $B$. abortus, which can be identified in aborted fetal material (SCHELLING et al., 2003; MUMA et al., 2007). Given its importance in public health, bovine brucellosis should be highlighted for its challenges to the international shipping of livestock and products of animal origin. In addition to these aspects, infection with Brucella spp. causes economic losses to livestock production around the world (AL DAHOUK et al., 2005). 
Considering the risk that brucellosis represents to human and animal populations, especially for people who work in slaughterhouses, this study aimed to determine the prevalence of $B$. abortus infection in workers of two slaughterhouses in the metropolitan area of Cuiaba in the state of Mato Grosso, Brazil; the associated risk factors, and the prevalence of infection in the animals slaughtered in these establishments.

This study was performed at two slaughterhouses in the metropolitan area of Cuiabá in the state of Mato Grosso, Brazil; that were under surveillance by The Health Inspection Service of the State Institute of Agricultural Protection of Mato Grosso (MT-INDEA). The project was approved by the University of Cuiabá Ethics Committee - UNIC 003/05

The owners of the slaughterhouses and the health inspection staff were contacted to authorize this research. Sectoral meetings were held with all of the employees to inform them of the damage that brucellosis causes to public health and livestock production and the methods of transmission, control and treatment. The importance of this type of research was also highlighted, focusing on its goals and methodology, and was aimed at raising awareness and obtaining consent for this study.

Data collection from the slaughterhouse workers covered the following sections: general services (reception of the animals, scales, cold storage, shipping and patio), slaughterer (bleeding, skinning, eviscerating, carcass trimming, washing of carcass and deboning), support (kitchen, cleaning, reception, observation and administrative area of the slaughterhouse), transport, inspection and the rendering plant (veterinarian and assistants).

Blood samples were collected after the formal approval of $100 \%$ of the employees working in each section of the slaughterhouses. Using suitable antiseptic procedures, cephalic vein puncture was performed by the Faculty of Pharmacy staff of the University of Cuiabá with sterilized and disposable equipment. The blood samples were collected in 10 $\mathrm{mL}$ test tubes without anticoagulant. After collection, the blood samples were stored at approximately $4^{\circ} \mathrm{C}$ in an isothermal box and centrifuged at $900 \mathrm{~g}$ for 10 minutes. The serums obtained were placed in plastic tubes that were previously identified and stored in a freezer at $-18^{\circ} \mathrm{C}$. Subsequently, the analysis was performed in the microbiology laboratory of the Faculty of Pharmacy and Biochemistry of the University of Cuiabá.

The buffered acidified antigen test (Rose Bengal) for B. abortus was performed as screening and interpreted in accordance with the manufacturer's instructions (Institute of Technology of Paraná TECPAR, Curitiba, PR). The positive samples were sent to the Laboratory of Bacterial Diseases of the Reproductive Biology Institute of São Paulo for the analysis of the complement fixation reaction (RFC) with B. abortus, standard technique for confirmatory diagnosis of brucellosis in positive serum triage, which was interpreted according to the pattern (The Central Laboratory of the United Kingdom, London, England). Because RFC is a more sensitive and specific test for the detection of $B$. abortus antibodies, the employees who were initially classified as serum reactive by the screening test were confirmed as seropositive by RFC.

For the possible characterization of risk factors that were important in the transmission of brucellosis, an analysis of association was carried out between the occurrence of the infection in humans and information related to their jobs, such as section and years of service; whether protective equipment (PPE) was used; whether there was contact with meat, blood, fetuses or viscera of animals; previous involvement with the occupation in rural areas; and prior consumption of dairy products without heat treatment. Furthermore, a survey of the occurrence of symptoms related to brucellosis, such as frequent headaches, intermittent fever, myalgia and joint pain, was performed through the administration of questionnaires to the slaughterhouses workers. 
To identify seropositive animals on the day of slaughter and blood collection from the staff of the slaughterhouses and to determine the prevalence of brucellosis in cows of reproductive age (over 24 months) slaughtered on that day, blood samples were collected from these animals. Blood was collected through jugular vein puncture before bleeding. Approximately 10 minutes after blood collection, the blood samples were stored at approximately $4^{\circ} \mathrm{C}$ in an isothermal box. At the Laboratory of Microbiology, Faculty of Veterinary Medicine of the University of Cuiabá - UNIC, the samples were centrifuged at $900 \mathrm{~g}$ for 10 minutes. The serum were transferred to plastic tubes and stored in a freezer at $-18^{\circ} \mathrm{C}$.

Initially, the occurrence of infection was determined using the Rose Bengal test, and confirmation was obtained through the slow agglutination serum (SAS) and 2-mercaptoethanol (2-ME) tests for Brucella abortus. The results were interpreted according to the current legislation (BRASIL, 2006).

The data on the prevalence of brucellosis in humans and animals and the relationship between the prevalence of human brucellosis and occupation were analyzed using the Fisher exact test. Risk factors were assessed using descriptive statistics.

Information concerning occupational activities and exposure to risk factors for infection by $B$. abortus was collected from all workers: 134 people in total from the two slaughterhouses. Table 1 shows the distribution of workers in relation to the work section at both slaughterhouses.

Table 1. Distribution of workers according to the working section at the slaughterhouses.

\begin{tabular}{|c|c|c|c|c|c|c|c|c|c|c|c|c|c|}
\hline \multirow{2}{*}{$\begin{array}{l}\text { Slaughter- } \\
\text { house }\end{array}$} & \multirow{2}{*}{$\begin{array}{l}\text { Number of } \\
\text { employees }\end{array}$} & \multicolumn{2}{|c|}{ Support } & \multicolumn{2}{|c|}{$\begin{array}{c}\text { Rendering } \\
\text { plant }\end{array}$} & \multicolumn{2}{|c|}{ Inspection } & \multicolumn{2}{|c|}{ Slaughterer } & \multicolumn{2}{|c|}{$\begin{array}{l}\text { General } \\
\text { services }\end{array}$} & \multicolumn{2}{|c|}{ Transport } \\
\hline & & $\mathrm{n}^{\circ}$ & $\%$ & $\mathrm{n}^{\mathrm{o}}$ & $\%$ & $\mathrm{n}^{\circ}$ & $\%$ & $\mathrm{n}^{\mathrm{o}}$ & $\%$ & $\mathrm{n}^{\mathrm{o}}$ & $\%$ & $\mathrm{n}^{\circ}$ & $\%$ \\
\hline $\mathrm{A}$ & 76 & 07 & 9.2 & 04 & 5.3 & 07 & 9.2 & 39 & 51.3 & 13 & 17.1 & 06 & 7.9 \\
\hline B & 58 & 02 & 3.5 & 00 & 0.0 & 05 & 8.6 & 36 & 62.1 & 12 & 20.6 & 03 & 5.2 \\
\hline
\end{tabular}

Source: Elaboration of the authors.

Six $(4.5 \%)$ out of 134 employees were reactive to $B$. abortus by $\mathrm{RFC}$ (one of which was the slaughterhouse A and the other five were slaughterhouse B), and they worked as slaughterers. In this study, we found a significant association $(\mathrm{P}<0.05)$ for the prevalence of brucellosis in slaughterers compared with other occupations in the slaughterhouses. There was no difference $(\mathrm{P}>0.05)$ in the prevalence of human brucellosis between the two slaughterhouses.

Information related to risk factors associated with the transmission of brucellosis was obtained from seropositive workers (Table 2). In this study, there was no difference $(\mathrm{P}>0.05)$ between the occurrence of the disease and the use of PPE.

In assessing the prevalence of brucellosis in 468 slaughtered cows in both slaughterhouses on the day of collection of the material for serologic evaluation of the workers, a higher $(\mathrm{P}<0.01)$ number of seropositive cows (24/158) 15.2\% were found in slaughterhouse B compared with slaughterhouse A (11/310) 3.5\%, and a total of 35 (7.5\%) cows were seropositive for B. abortus by the 2-ME test. 
Table 2. Positions and risk factors associated with the transmission of brucellosis related to seropositive workers.

Gender: M (male); Slaughterer: time spent as a slaughterer; Occupation: if the person has worked in the same occupation previously; Contact: previous contact with meat, blood, viscera or fetal animals without adequate protection; Rural area: if the person has lived in a rural area; Dairy product: consumption of milk or dairy products; Symptoms: if the person has or has had some of the symptoms characteristic of human brucellosis (headache, intermittent fever, and joint pain); PPE: if the person uses personal protective equipment (gloves, goggles, and aprons) during their work activities.

\begin{tabular}{ccccccccccc}
\hline $\begin{array}{c}\text { Slaughter- } \\
\text { house }\end{array}$ & $\begin{array}{c}\text { Seropositi-ve } \\
\text { employee }\end{array}$ & $\begin{array}{c}\text { Age (years } \\
\text { old) }\end{array}$ & Sex & $\begin{array}{c}\text { Slaught. } \\
\text { (years) }\end{array}$ & Occup. & Cont. & $\begin{array}{c}\text { Rural } \\
\text { area }\end{array}$ & $\begin{array}{c}\text { Dairy } \\
\text { prod. }\end{array}$ & Sympt. & PPE \\
\hline A & 1 & 48 & M & 4 & Yes & Yes & No & No & No & No \\
B & 2 & 31 & M & 1 & Yes & Yes & No & Yes & No & Yes \\
B & 3 & 24 & M & 1 & Yes & Yes & Yes & Yes & No & No \\
B & 4 & 39 & M & 4 & Yes & Yes & No & No & Yes & Yes \\
B & 5 & 26 & M & 2 & No & Yes & No & Yes & Yes & No \\
B & 6 & 36 & M & 3 & No & Yes & Yes & Yes & No & No \\
\hline
\end{tabular}

Source: Elaboration of the authors.

As noted in Table 1, usually, in slaughterhouses, the position of slaughterer, which involves bleeding, skinning, eviscerating, carcass trimming, washing the carcass and deboning, has a greater number of workers. This is a risky occupation for brucellosis transmission because the workers have contact with the carcasses of slaughtered animals.

There was no difference $(\mathrm{P}>0.05)$ in the prevalence of human brucellosis between the two slaughterhouses, which may be because of the small number of staff in each slaughterhouse and seropositive workers. These results are close to those observed by Martínez, Vásquez e Kourany (1977), who obtained a $6.2 \%$ prevalence of brucellosis in slaughterhouse workers in Panama. Lacerda et al. (2000) and Santos et al. (2007) reported a prevalence of $10.2 \%$ and $10.1 \%$ of brucellosis, respectively, in slaughterhouse workers in São Luís - MA.

All of the workers who were positive for $B$. abortus from both slaughterhouses were male and worked as slaughterers; thus, they were exposed to direct contact with meat, blood, viscera and bovine fetuses. All seropositive workers were male because the position of slaughterer was only filled by men in both slaughterhouses (Table 2). Similar data were observed by Lacerda et al. (2000).
In this study, four seropositive workers had previously worked as slaughterers, and they reported no symptoms compatible with brucellosis, did not use PPE and had consumed dairy products without heat treatment. Their ages ranged from 26 to 48 years old, and they had worked as slaughterers for one to four years.

From the data obtained, analysis simulation was performed using the $\mathrm{T}$ test as a reference. For a significance level of $5 \%$ and estimated error of $5 \%$, an optimal sample size of 232 individuals was recommended. Because only 134 employees were available, it is understood that our sample size was not sufficient to detect a significant influence of the use of PPE. However, we note that four seropositive individuals did not use PPE.

From the information obtained from workers who were seronegative for brucellosis, $85.2 \%$ (slaughterhouse A) and $84.9 \%$ (slaughterhouse B) reported previous contact with bovine meat or viscera; however, $72.0 \%$ (slaughterhouse A) and $69.3 \%$ (slaughterhouse B) reported the regular use of PPE. This finding that most seronegative employees used PPE reinforces the importance of its use as a preventive measure in occupations at risk for contamination, primarily slaughterers. 
The prevalence of seropositive animals slaughtered (15.2\% prevalence in slaughterhouse B) was larger than previously observed by Monteiro et al. (2006) in beef cattle (5.6\%) in an extract of Mato Grosso do Sul, Brazil, and the prevalence of $10.2 \%$ found in a study of the epidemiology of brucellosis in the state of Mato Grosso in 2003 (NEGREIROS et al., 2009). Because the current law requires that animals that are seropositive for brucellosis be slaughtered, this may explain the higher prevalence of brucellosis in slaughtered cows. However, the presence of cows that were seropositive for brucellosis in the batch of animals slaughtered that day was not communicated to the slaughterhouses. Coincidentally, a higher but not statistically significant prevalence of workers who were seropositive for $B$. abortus was observed at slaughterhouse B. The slaughter of animals that are seropositive for $B$. abortus is characterized as a risk factor in the transmission of the disease to slaughterhouse workers or workers from any other establishment that handles the blood, flesh or viscera of seropositive animals for brucellosis. This is especially true when the seropositive animals are not properly reported and the necessary steps are not taken to protect the personal safety of the people involved in these activities.

It is noteworthy that legally mandated procedures applicable to the presence of seropositive animals were not followed. According to the current legislation, animals that are seropositive for brucellosis should be identified (a P mark made by a red-hot iron on the right cheek), and they should also be slaughtered separately at the end of the slaughter shift (BRASIL, 2006), enabling the employees to take measures to avoid contamination. These findings reflect the need for increased awareness and surveillance measures to ensure that the farmers abide by the necessary legal procedures to dispose of animals that are seropositive for brucellosis.

Slaughterhouse workers are susceptible to $B$. abortus infection; at both slaughterhouses, the workers who were positive for brucellosis were slaughterers. This occupation and the slaughtering of animals that are seropositive for brucellosis are risk factors for the transmission of the disease to slaughterhouse workers.

Cows that were seropositive for B. abortus were slaughtered at the two slaughterhouses without the proper information and necessary procedures, which are essential for safe, sanitary slaughter.

Most individuals who were seropositive for $B$. abortus did not use personal protective equipment, which is a risk factor in the transmission of the disease to slaughterhouse workers.

This study is expected to serve as a tool to alert public health officials, health inspectors, owners, slaughterhouse workers and ranchers that preventive and corrective measures should be adopted to reduce the risks of contamination, consequently improving the health and quality of life of these employees.

\section{Acknowledgments}

We thank workers in all sections of the slaughterhouses for providing biological material, and University of Cuiabá - UNIC for providing laboratories support for the exams.

\section{References}

AL DAHOUK, S.; TOMASO, H.; PRENGERBERNINGHOFF, E.; SPLETTSTOESSER, W. A.; SCHOLZ, H. C.; NEUBAUER, H. Identification of Brucella species and biotypes using polymerase chain reaction-restriction fragment length polymorphism (PCR-RFLP). Critical Reviews in Microbiology, New York, v. 31, n. 4, p. 191-196, 2005.

BRASIL. Manual técnico do programa nacional de controle e erradicação da brucelose e da tuberculose PNCEBT. Brasília: Ministério da Agricultura, Pecuária e Abastecimento, Programa Nacional de Controle e Erradicação da Brucelose e Tuberculose MAPA/DSA/ DAS, 2006, $184 \mathrm{p}$.

GODFROID, J.; CLOECKAERT, A.; LIAUTARD, J. P.; KOHLER, S.; FRETIN, D.; WALRAVENS, K.; GARINBASTUJI, B.; LETESSON, J. J. From the discovery of the Malta fever's agent to the discovery of a marine 
mammal reservoir, brucellosis has continuously been a re-emerging zoonosis. Veterinary Research, London, v. 36, n. 3, p. 313-326, 2005.

GODFROID, J.; SCHOLZ, H. C.; BARBIER, T.; NICOLAS, C.; WATTIAU, P.; FRETIN, D.; WHATMORE, A. M.; CLOECKAERT, A.; BLASCO, J. M.; MORIYON, I.; SAEGERMAN, C.; MUMA, J. B.; AL DAHOUK, S.; NEUBAUER, H.; LETESSON, J. J. Brucellosis at the animal/ecosystem/human interface at the beginning of the 21 st century. Preventive Veterinary Medicine, Netherlands, v. 102, n. 2, p. 118-131, 2011.

LACERDA, L. M.; ALVES, L. M. C.; MATHIAS, L. A.; RODRIGUES, A. L. B. Brucelose em trabalhadores de matadouros do município de São Luis/MA. Revista Higiene Alimentar. Mirandópolis, v. 14, n. 68-69, p. 6265, 2000.

MARTÍNEZ, R.; VÁSQUEZ, M. A.; KOURANY, M. Aspectos epidemiologicos de la brucelosis en la poblacion de alto riesgo en Panamá. Boletin de la Oficina Sanitaria Panamericana, Washington, v. 83, n. 2, p. 140147, 1977.

MONTEIRO, L. A. R. C.; PELlEGRIN, A. O.; ISHIKAWA, M. M.; OSÓRIO, A. L. A. R. Investigação epidemiológica da brucelose bovina em um estrato do Estado de Mato Grosso do Sul. Pesquisa Veterinária Brasileira, Rio de Janeiro, v. 26, n. 4, p. 217-222, 2006.

MUMA, J. B.; GODFROID, J.; SAMUI, K. L.; SKJERVE, E. The role of Brucella infection in abortions among traditional cattle reared in proximity to wildlife on the Kafue flats of Zambia. Revue Scientifique et Technique - Office International des Epizooties, Paris, v. 26, n. 3, p. 721-730, 2007.

NEGREIROS, R. L.; DIAS, R. A.; FERREIRA, F.; FERREIRA NETO, J. S.; GONÇALVES, V. S. P.; SILVA, M. C. P.; FIGUEIREDO, V. C. F.; LÔBO, J. R.; FREITAS, J.; AMAKU, M. Situação epidemiológica da brucelose bovina no Estado de Mato Grosso. Arquivo Brasileiro Medicina Veterinária e Zootecnia, Belo Horizonte, v. 61, p. 56-65, 2009. Suplemento 1.

NETA, A. V. C.; MOL, J. P. S.; XAVIER, M. N.; PAIXO, T. A.; LAGE, A. P.; SANTOS, R. L. Pathogenesis of bovine brucellosis. The Veterinary Journal, Netherlands, v. 184, n. 2, p. 146-155, 2010.

SANTOS, H. P.; TEIXEIRA, W. C.; OLIVEIRA, M. M. M.; PEREIRA, H. M.; OLIVEIRA, R. A.; NEGREIROS, R. C.; SOARES FILHO, P. M.; SANTANA, S. S.; CASTRO, R. S. Brucelose bovina e humana diagnosticada em matadouro municipal de São Luís MA, Brasil. Ciência Veterinária dos Trópicos, Recife, v. 10, n. 2-3, p. 86-94, 2007.

SCHELlinG, E.; DIGUIMBAYE, C.; DAOUD, S.; NICOLET, J.; BOERLIN, P.; TANNER, M.; ZINSSTAG, J. Brucellosis and Q-fever seroprevalences of nomadic pastoralists and their livestock in Chad. Preventive Veterinary Medicine, Netherlands, v. 61, n. 4, p. 279-293, 2003. 
